\title{
Suppression of Powdery Mildew in Okra and Sunflower Plants under Natural Infection through Peroxyacetic Acid Foliar Application \\ Anwar A. Galal
}

Plant Pathology Dept., Faculty of Agriculture, Minia University, Minia, Egypt

\begin{abstract}
pplication of an eco-friendly hydrogen peroxide-based $A$ compound peroxyacetic acid (PAA), to leaves of okra and sunflower plants significantly reduced infection with powdery mildew. The maximum percent disease control was recorded with acetic acid (AA) + hydrogen peroxide $\left(\mathrm{H}_{2} \mathrm{O}_{2}\right)$ mixture at $0.2 \mathrm{~g} / \mathrm{l} \mathrm{AA}+2.0 \mathrm{~g} / 1 \mathrm{H}_{2} \mathrm{O}_{2}$ concentration, being 69.28 and $70.07 \%$, when okra and sunflower plants were sprayed three times, respectively along 2 growing seasons. Decreasing sprayings and mixture concentration reduced percent of powdery mildew control. Accordingly, PAA showed a beneficial role to control powdery mildew of either okra or sunflower plants. Thus, PAA could be recommended for integrated disease management program (IDM) against powdery mildew of okra and sunflower.
\end{abstract}

Keywords: Abelmoschus esculentus, Erysiphe cichoracearum, Golovinomyces cichoracearum, Helianthus annuus, Okra, peroxyacetic acid, powdery mildew and sunflower.

Powdery mildew is one of the most common fungal diseases affecting wide range of host plants. Disease symptoms are easily spotted; however, it can spread to the point of being out of control quickly. The term "powdery mildew" encompasses a range of related fungal species which all possess similar damage symptoms with each targeting specific hosts. Powdery mildew is a serious disease of okra and sunflower plants in Assuit and Minia governorates, Egypt (Ismail et al., 2012 \& Younes and Abo-Elyouser, 2012). The disease is caused by the fungus Golovinomyces cichoracearum, formerly named Erysiphe cichoracearum DC ex Merat (Ale-Agha et al., 2008; Shah et al., 2016; Dahivelkar et al., 2017 and Madhusudhan et al., 2017). This disease is one of the most commonly occurring diseases on okra (Abelmoschus esculentus Moench) and sunflower (Helianthus annunnus L.). Most of their cultivars are susceptible to powdery mildew, and depending in most cases, upon the age of the plant at the time of infection. The pathogen is easily recognized by the abundant production of mycelia, conidiophores and conidia on the surface of leaves (Gogol et al., 2013; Shah et al., 2016; Dahivelkar et al., 2017 and Madhusudhan et al., 2017).

Powdery mildew reduces the photosynthetic rate of plants, causes yellowing and premature death of leaves and, in severe infections, may kill the plant. The reduction in leaf area and changes in the carbohydrate contents of infected leaves can reduce plant yield as well (Karuna et al., 2011; Gogol et al., 2013; Dahivelkar et al., 2017; Suresha et al., 2017 and Madhusudhan et al., 2017). Several approaches 
such as fungicides (Naik and Nagaraja, 2000; Kumar et al., 2008; Dhutraj, 2011; Madhusudhan et al., 2017 and Dahivelkar et al., 2017), plant extracts (El-Fahar and Mostafa, 2009; Gado, 2013 and Zhang et al., 2016), bioagents (Kumar et al., 2008 and Khalikar et al., 2011), resistance inducers (Abada et al., 2008 and Ismail et al., 2012), algae extracts (Zhang et al., 2016), nanoparicles of sulphur (Gogol et al., 2013 and Reuveni et al., 2017) and potassium silicate (Liang et al., 2005; Kanto et al., 2006; Yanar et al. 2011 and Dallagnol et al., 2012) were approved to managing powdery mildews in various plants. Unfortunately, powdery mildew pathogens are still a complex issue to be controlled, due to raising fungicide resistance strains, repeat infection frequently and a few field resistant cultivars produced (McGrath, 2001; Gogol et al., 2013; Suresha et al., 2017; Dahivelkar et al., 2017 and Madhusudhan et al., 2017). However, the genetic resistance against powdery mildew is not durable because of rapid genetic changes within the pathogen population (Shah et al., 2016). For this reason, chemicals are also used as a control method. However, there are several reports on the selection of isolates either resistant or insensitive to different groups of fungicides (McGrath, 2001; Gogol et al., 2013; Kulkarni et al., 2015; Dahivelkar et al., 2017 and Madhusudhan et al., 2017). Thus, the development of additional control measures with low environmental impact represents an important research topic for this disease.

The use of peroxyacetic acid (PAA) is gaining attention due to their proven strong oxidizer, bio degradability, low toxicity and no residual toxicity in the ecosystem. So, PAA which has broad-spectrum antimicrobial properties was used in the present study. The present study was under taken to find out the most suitable PAA concentration for controlling the disease.

\section{Materials and Methods}

Preparation of PAA:

Three combinations ( $\mathrm{g} /$ liter distilled water) for hydrogen peroxide and acetic acid which led to form peroxyacetic acid (PAA), as previously reported (EPA, 2004; Buschmann and Del Negro, 2012 and EPA, 2012) e.g., 0.05AA + $1.0 \mathrm{H}_{2} \mathrm{O}_{2}, 0.1$ AA $+1.0 \mathrm{H}_{2} \mathrm{O}_{2}$ and $0.2+2 \mathrm{H}_{2} \mathrm{O}_{2}$ were tested and distilled water was served as control.

\section{Field experiments:}

Disease severity of powdery mildew was rated weekly beginning at 2 weeks after the last foliar spraying. Each plant was visually rated for disease severity based on estimation of the percentage of the leaf surfaces covered with powdery mildew lesions on fully expanded 5 leaves (from leaf number 4 to leaf number 8 per plant). Values of AUDPC were calculated based on the formula as follows:

$$
\Sigma[\{(\mathrm{xi}+\mathrm{xi}-1) / 2\}(\mathrm{ti}-\mathrm{ti}-1)]
$$

Where $\mathrm{xi}$ is the rating at each evaluation time and (ti $-\mathrm{ti}-1)$ is the time between evaluations as described by Zhang et al. (2016). 
Statistical analysis:

The least significant difference (LSD) at $P=0.05$ for AUDPC values of all treatments along 2 seasons per each plant individually was calculated (Gomez and Gomez, 1994).

\section{R e s u l t s}

Okra powdery mildew:

Among acetic acid $+\mathrm{H}_{2} \mathrm{O}_{2}$ foliar applications, a significant reduction in powdery mildew AUDPC values was obtained as compared to untreated okra plants (Table 1). The least percentage ( $6.96 \%$ on the average) in powdery mildew protection under natural infection was provided when okra plants were sprayed once only by the tested solutions. The highest protection percentage, being $43.74 \%$ on the average was exhibited when the foliar was sprayed three times by AA $+\mathrm{H}_{2} \mathrm{O}_{2}$ mixture followed by the two sprays program (30.91\% protection on the average). However, increasing $\mathrm{AA}+\mathrm{H}_{2} \mathrm{O}_{2}$ concentrations significantly increased powdery mildew protection. To be noticed, one time foliar spray by lower $\mathrm{AA}+\mathrm{H}_{2} \mathrm{O}_{2}$ concentrations explored insignificant powdery mildew protection, since single foliar spraying by either $0.05 \mathrm{~g} / \mathrm{l} \mathrm{AA}+1.0 \mathrm{~g} / \mathrm{l} \mathrm{H}_{2} \mathrm{O}_{2}$ or $0.1 \mathrm{~g} / \mathrm{l} \mathrm{AA}+1.0 \mathrm{~g} / \mathrm{l} \mathrm{H}_{2} \mathrm{O}_{2}$ caused the lowest protection percentage $(0.73 \%)$. The highest concentration tested $0.2 \mathrm{~g} / \mathrm{l}$ acetic acid + $2.0 \mathrm{~g} / \mathrm{l} \mathrm{H}_{2} \mathrm{O}_{2}$ significantly decreased powdery mildew even when it was applied one time spray (19.42\% protection). On the other hand, significant powdery mildew reduction was achieved when all $\mathrm{AA}+\mathrm{H}_{2} \mathrm{O}_{2}$ concentrations were applied twice or thrice to okra foliar. The three times foliar spray program by $\mathrm{AA}+\mathrm{H}_{2} \mathrm{O}_{2}$ showed the highest protection percentages. At $0.2 \mathrm{~g} / 1 \mathrm{AA}+2.0 \mathrm{~g} / \mathrm{l} \mathrm{H}_{2} \mathrm{O}_{2}$ the least AUDPC values for powdery mildew along the two growing seasons tested (199 and 220 in 2016 and 2017 growing seasons, respectively). As for growing season, AUDPC values of okra powdery mildew under natural infection were significantly higher for untreated plants in 2016 (712 AUDPC values) than in 2017 (652 AUDPC values). Furthermore, in most cases effectiveness of AA+ $\mathrm{H}_{2} \mathrm{O}_{2}$ to reduce okra powdery mildew was more in 2016 than in 2017 growing season.

\section{Sunflower powdery mildew:}

Generally, all AA $+\mathrm{H}_{2} \mathrm{O}_{2}$ treatments tested showed significant reduction in sunflower powdery mildew as compared to untreated plants, under natural infection throughout the two growing seasons (Table 2). Among spraying times, the three times foliar sprays program by AA $+\mathrm{H}_{2} \mathrm{O}_{2}$ expressed the highest protection percentages (37.81\% on the average) followed by the two sprays program $(29.29 \%$ protection on the average) against sunflower powdery mildew. Single foliar spray program by $\mathrm{AA}+\mathrm{H}_{2} \mathrm{O}_{2}$ concentrations tested showed the lowest protection percentage $(22.27 \%)$. As for $\mathrm{AA}+\mathrm{H}_{2} \mathrm{O}_{2}$ combinations tested, all of them exhibited significant reduction in sunflower powdery mildew. Increasing $\mathrm{AA}+\mathrm{H}_{2} \mathrm{O}_{2}$ concentration increased powdery mildew reduction. Concomitantly raising spray times enhanced $\mathrm{AA}+\mathrm{H}_{2} \mathrm{O}_{2}$ efficiency to reduce AUDPC values for sunflower powdery mildew, since the highest protection percentage $(70.07 \%)$ was provided by the three times foliar spray program with $0.2 \mathrm{~g} / \mathrm{l} \mathrm{AA}+2.0 \mathrm{~g} / 1 \mathrm{H}_{2} \mathrm{O}_{2}$ followed by the two application program of the same concentration $(56.5 \%)$. During the two growing 
seasons, AUDPC values of sunflower powdery mildew on the untreated plants were significantly higher in 2017 (698 AUDPC values) than in 2016 (654 AUDPC values).

Table 1. Area under powdery mildew progress curve values to okra plants as affected by different sprayings by PAA

\begin{tabular}{|c|c|c|c|c|}
\hline \multirow{2}{*}{$\begin{array}{l}\text { Spray treatments and } \\
\text { Cons. }(\mathrm{g} / \mathrm{l})\end{array}$} & \multicolumn{2}{|c|}{ Growing season, } & \multirow{2}{*}{ Mean } & \multirow{2}{*}{ Protection $\%$} \\
\hline & 2016 & 2017 & & \\
\hline \multicolumn{5}{|l|}{$\begin{array}{l}\text { One spray } \\
\mathrm{AA}+\mathrm{H}_{2} \mathrm{O}_{2}\end{array}$} \\
\hline $0.05+1.0$ & 702 & 652 & 677 & 0.73 \\
\hline $0.1+1.0$ & 702 & 652 & 677 & 0.73 \\
\hline $0.2+2.0$ & 594 & 505 & 549.5 & 19.42 \\
\hline Mean & 666 & 603 & 634.5 & 6.96 \\
\hline \multicolumn{5}{|l|}{$\begin{array}{c}\text { Twice sprays } \\
\mathrm{AA}+\mathrm{H}_{2} \mathrm{O}_{2}\end{array}$} \\
\hline $0.05+1.0$ & 572 & 529 & 550.5 & 19.28 \\
\hline $0.1+1.0$ & 500 & 481 & 490.5 & 28.08 \\
\hline $0.2+2.0$ & 369 & 376 & 372.5 & 45.38 \\
\hline Mean & 480.33 & 462 & 471.16 & 30.91 \\
\hline \multicolumn{5}{|l|}{$\begin{array}{c}\text { Triple sprays } \\
\mathrm{AA}+\mathrm{H}_{2} \mathrm{O}_{2}\end{array}$} \\
\hline $0.05+1.0$ & 545 & 524 & 534.5 & 21.62 \\
\hline $0.1+1.0$ & 424 & 390 & 407 & 40.32 \\
\hline $0.2+2.0$ & 199 & 220 & 209.5 & 69.28 \\
\hline Mean & 389.33 & 378 & 383.66 & 43.74 \\
\hline Untreated & 712 & 652 & 682 & 0.0 \\
\hline Grand Mean & 561.9 & 523.75 & 542.83 & \\
\hline
\end{tabular}

LSD at 0.05 for Spraying numbers $=9.11$ Growing seasons $=12.5$

PAA concentrations $=14.8$ 
Table 2. Area under powdery mildew progress curve values to sunflower plants as affected by different sprayings by PAA

\begin{tabular}{|c|c|c|c|c|}
\hline $\begin{array}{c}\text { Spray treatments and } \\
\text { Cons. }(\mathrm{g} / \mathrm{l})\end{array}$ & \multicolumn{2}{|c|}{ Growing season, } & \multirow{2}{*}{ Mean } & $\begin{array}{c}\text { Protection } \\
\%\end{array}$ \\
\cline { 2 - 3 } One spray & 2016 & 2017 & & \\
$\mathrm{AA}+\mathrm{H}_{2} \mathrm{O}_{2}$ & & & & \\
$0.05+1.0$ & 644 & 637 & 640.5 & 6.97 \\
$0.1+1.0$ & 476 & 556 & 516 & 25.05 \\
$0.2+2.0$ & 394 & 504 & 449 & 34.78 \\
\hline Mean & 504.66 & 565.66 & 535.16 & 22.27 \\
\hline Two sprays & & & & \\
$\mathrm{AA}+\mathrm{H}_{2} \mathrm{O}_{2}$ & & & & \\
$0.05+1.0$ & 644 & 623 & 633.5 & 7.98 \\
$0.1+1.0$ & 560 & 444 & 502 & 27.08 \\
$0.2+2.0$ & 280 & 371 & 325.5 & 52.79 \\
\hline Mean & 494.66 & 479.33 & 486.83 & 29.29 \\
\hline Three sprays & & & & \\
AA+ $\mathrm{H}_{2} \mathrm{O}_{2}$ & & & & \\
$0.05+1.0$ & 616 & 518 & 567 & 17.64 \\
$0.1+1.0$ & 546 & 476 & 511 & 25.78 \\
\hline $.2+2.0$ & 231 & 182 & 206.5 & 70.07 \\
\hline Mean & 464.33 & 392 & 428.16 & 37.81 \\
\hline Untreated & 679 & 698 & 688.5 & \\
\hline Grand Mean & 535.66 & 533.74 & 534.66 & \\
\hline
\end{tabular}

LSD at 0.05 for Sprayings $=12.6$ Growing seasons $=13.7$

PAA concentrations $=13.65$

\section{D i s c us s i o n}

The present study is concerned to test the efficiency of $\mathrm{AA}+\mathrm{H}_{2} \mathrm{O}_{2}$ combinations that form an eco-friendly $\mathrm{H}_{2} \mathrm{O}_{2}$-based compound named peroxyacetic acid (PAA) as reported by Buschmann and Del Negro (2012). This PAA is successfully reacted as a strong oxidizer disinfectant, fungicide and bactericide compound (EPA, 2004; Hopkins et al., 2003; Hopkins et al., 2009 and Ayoub et al., 2017).

The results of the present study, along 2 growing seasons tested revealed that treatments with acetic acid $+\mathrm{H}_{2} \mathrm{O}_{2}$ were effective to reduce AUDPC values of powdery mildew in either okra or sunflower plants significantly. Least percentages (6.96 and $22.27 \%$ ) in powdery mildew protection under natural infection were provided when okra and sunflower plants, respectively were sprayed one time by the tested solutions. The highest protection percentages, $43.74 \%$ for okra and $37.81 \%$ for sunflower, were exhibited when the foliar was sprayed three times by the tested solutions where the two sprays program exhibited 30.91 and $29.29 \%$ protection in case of okra and sunflower, respectively. However, increasing AA $+\mathrm{H}_{2} \mathrm{O}_{2}$ concentrations significantly enhanced powdery mildew protection. To be noticed, one time foliar spray program by lower AA $+\mathrm{H}_{2} \mathrm{O}_{2}$ concentrations explored 
insignificant powdery mildew protection, particularly in case of okra plants. Since one time foliar spraying program by either $0.05 \mathrm{~g} / \mathrm{l} \mathrm{AA}+1.0 \mathrm{~g} / 1 \mathrm{H}_{2} \mathrm{O}_{2}$ or $0.1 \mathrm{~g} / \mathrm{l} \mathrm{AA}$ $+1.0 \mathrm{~g} / \mathrm{l} \mathrm{H}_{2} \mathrm{O}_{2}$ caused more or less $0.73 \%$ protection, (AUDPC values) merely to check ones, while sunflower plants provided 6.97 and $25.05 \%$ powdery mildew protection by one time program using $0.05 \mathrm{~g} / \mathrm{l} \mathrm{AA}+1.0 \mathrm{~g} / 1 \mathrm{H}_{2} \mathrm{O}_{2}$ or $0.1 \mathrm{~g} / \mathrm{l} \mathrm{AA}+1.0$ $\mathrm{g} / \mathrm{H} \mathrm{H}_{2} \mathrm{O}_{2}$ foliar spray, respectively.

The highest concentration tested $0.2 \mathrm{~g} / \mathrm{l} \mathrm{AA}+2.0 \mathrm{~g} / 1 \mathrm{H}_{2} \mathrm{O}_{2}$ decreased powdery mildew significantly event even when it applied one time spray which caused 19.42 and $34.78 \%$ powdery mildew reduction in okra and sunflower plants, respectively. On the other hand, all tested solutions of $\mathrm{AA}+\mathrm{H}_{2} \mathrm{O}_{2}$ significantly protected okra and sunflower against powdery mildew when they were applied twice or thrice. At 0.2 $\mathrm{g} / \mathrm{AA}+2 \mathrm{~g} / 1 \mathrm{H}_{2} \mathrm{O}_{2}$ the least AUDPC values for powdery mildew along 2 growing seasons tested recorded 199 and 220 AUDPC values in 2016 and 2017 growing seasons, respectively in case of okra powdery mildew. While in sunflower powdery mildew, the same concentration recorded 231 and 182 AUDPC values in 2-16 and 2017 growing seasons, respectively. As for growing seasons, AUDPC values of okra powdery mildew under natural infection was higher significantly for untreated plants in 2016 (712 AUDPC valuea) than 2017 (652 AUDPC values). Furthermore, effectiveness of $\mathrm{AA}+\mathrm{H}_{2} \mathrm{O}_{2}$ to reduce okra powdery mildew was more significant in 2016 than 2017 growing season.

In the light of the present data, it can be concluded that $\mathrm{H}_{2} \mathrm{O}_{2}$-based compound which called PAA has a beneficial effect to suppress powdery mildew development in either okra or sunflower plants tested. Three times PAA foliar sprays program gave the highest protection against powdery mildew specially when okra or sunflower plants were sprayed by the concentration $0.2 \mathrm{~g} / \mathrm{l} \mathrm{AA}+2.0 \mathrm{~g} / 1 \mathrm{H}_{2} \mathrm{O}_{2}$ that lowered AUDPC values of okra powdery mildew from 682 in case of untreated to 209.5 (69.28 \% protection) and from 688.5 to 206.5 (70.07\% protection) of sunflower powdery mildew. Data are in line with those obtained by PAA application against several plant diseases caused by either phytopathogenic fungi (Mari et al., 2004; Pukdee and Sardsud, 2007 Thipaksorn et al., 2012.; Feliziani et al., 2016 and Ayoub et al., 2017) or phytopathogenic bacteria (Hopkins et al., 2003 and Hopkins et al., 2009). Thus, the present study highly recommended including PAA in any integrated powdery mildew management programs against powdery mildew of okra and sunflower.

\section{Refere nces}

Abada, K.A.; Hilall, M.R. and Mostafa, S. H. 2008. Induced resistance against powdery mildew in cucumber. J. Biol. Chem. Environ. Sci., 3: 45-56.

Ale-Agha, N.; Boyle, H.; Braun, U.; Butin, H.; Jage, H.; Kumer, V. and Chen, H.D. 2008. Taxonomy, host range and distribution of some powdery mildew fungi (Erysiphales). Schcchtendalia, 17: 30-54.

Egypt. J. Phytopathol., Vol. 45, No. 2 (2017) 
Ayoub, F.; Oujji, N.B.; Chebli, B.; Ayoub, M.; Hafidi, A.; Salghi, R. and Jodeh, S. 2017. Antifungal effectiveness of fungicide and peroxyacetic acid mixture on the growth of Botrytis cinerea. Microbial Pathogenesis, 105:74-80.

Buschmann, W. E. and Del Negro, A. S. 2012. Production of peroxycarboxylic acids. USA Patent US8318972B2. 845.

Dahivelkar, P.; Atre, G. E.; Gawande, P.V. and Mate, G.D. 2017. Management of powdery mildew of okra caused by Erysiphe cichoracearum. Int. J. Curr. Microbiol. App. Sci., 6(8):3183-3189.

Dallagnol, L. J.; Rodrigues, F. A.; Tanaka, F. A. O.; Amorim, L. and Camargo, L. E. A. 2012. Effect of potassium silicate on epidemic components of powdery mildew. Plant Pathology, 61: 323-330.

Dhutraj, D. N. 2011. Efficacy of fungicides and bioagents against powdery mildew of okra. J. Pl. Dis. Sci, 6(2):170-172.

El-Fahar, S. and Mostafa, S. M.E. 2009. Effect of some plant extracts and partial substitution of thiovit 80 by plant extract on powdery mildew disease of sugar beet. J. Agric. Sci. Mansoura Univ., 34(1):309-320.

EPA, 2004. Registration Eligibility Decision (RED) PAKTM 27 (sodium carbonate peroxyhydrate with active ingredient hydrogen peroxide), Human and Ecological Risk Assessment for Section 3 Registration of the end-use product PAKTM 27 for application to lakes, ponds, and drinking water reservoirs, DP\#301201, PC\#000595, EPA File Symbol No. 68660-O; US EPA, Office of Pesticide Program, November 9, 2004.14 Massachusetts Department of Environmental Protection Massachusetts Department of Agricultural Resources.

EPA. 2012. Alternative Disinfection Methods Fact Sheet: Peracetic Acid. US Environmental protection Agency, Office of Wastewater Management EPA 832-F-12-030 D.C.

Feliziani, E.; Lichterb, A.J.; Smilanickc, L. and Ippolito, A. 2016. Disinfecting agents for controlling fruit and vegetable diseases after harvest. Postharvest Biology and Technology, 122: 53-69.

Gado, E.A.M. 2013. Impact of treatment with some plant extracts and fungicides on sugar beet powdery mildew and yield components. Australian J. Basic and App. Sciences, 7(1):468-472.

Gogol, R.; Singh, P.K.; Kumar, R.; Nair, K.K.; Alam, I.; Srivastava, C.; Yadav, S.; Gopal, M.; Choudhury, S. R. and Goswami, A. 2013. Suitability of nanosulphur for biorational management of powdery mildew of okra (Abelmoschus esculentum Moench) caused by Erysiphe cichoracearum. J. Plant Pathol. Microb., 4:171.

Gomez, K.A. and Gomez, A.A. 1994. Statistical Procedures for Agricultural Research, $2^{\text {nd }}$ ed. New York, USA: John Wiley and Sons. 
Hopkins, D.L.; Hilgren, J.; Lovic, B. and Thompson, C.M. 2003. Wet seed treatment with peroxyacetic acid for the control of bacterial fruit blotch and other seed borne diseases of watermelon. Plant Disease, 87(12): 1495-1499.

Hopkins, D. L.; Thompson, C.M. and Lovic, B. 2009. Management of transplant house spread of Acidovorax avenae subsp. citrulli on cucurbits with bactericidal chemicals in irrigation water. Plant Health Progress, Website: http://www.plantmanagementnetwork.org/pub/php/research/2009/acidovorax

Ismail, M.E.; Galal, A.A. and Abdalla, H.M. 2012. Induction of resistance in sunflower plants against powdery mildew. Minia International Conference for Agriculture and Irrigation in the Nile Bain Countries, $26^{\text {th }}-29^{\text {th }}$ March, 2012, El-Minia, Egypt. Pp 99-104.

Kanto, T.; Miyoshi, A.; Ogawa, T.; Maekawa, K. and Aino, M. 2006. Suppressive effect of liquid potassium silicate on powdery mildew of strawberry in soil. J. General Plant Pathology, 72,137-42.

Karuna, K.; Shadakshari, Y.G.; Jagadish, K.S.; Geethas, K.N.; Khalikar, P.V.; Jagtap, G. P. and Sontakke PL. 2011. Management of sunflower powdery mildew caused by Erysiphe cichoracearum. Ann. Pl. Protect. Sci., 23(1):8389.

Khalikar, P.V.; Jagtap, G.P. and Sontakke, P. L. 2011. Management studies of okra powdery mildew (Erysiphe cichoracearum) using bio-agents, plant extracts and chemical fungicides. Indian Phytopath., 64(3):286-290.

Kulkarni, V.; Shankergoud, L. and Govindappa, M.R. 2015. Identification of sunflower powdery mildew resistance sources under artificial screening. SABRAO J. Breed. Genet., 47(4): 502-509.

Kumar, A.M.; Ganeshan, G.; Reddy, K.N. and Ramachandra, Y.L. 2008. Integrated disease management for the control of powdery mildew (Leviellula taurica (Lev.) Arn.) in bell pepper. The Asian and Australasian J Plant Science and Biotechnology, 2(2):107-112.

Liang, Y.C.; SunWC, Si. J. and Ro“mheld, V. 2005. Effects of foliar- and rootapplied silicon on the enhancement of induced resistance to powdery mildew in Cucumis sativus. Plant Pathology, 54, 678-85.

Mari, M., R. Gregori., and I. Donati. 2004. Postharvest control of Monilinia laxa and Rhizopus stolonifer in stone fruit by peracetic acid. Postharvest Biology and Technology. 33:319-325.

McGrath, M.T. 2001. Fungicide resistance in cucurbit powdery mildew: experiences and challenges. Plant Disease, 85, 236-45.

Madhusudhan, P.; Narasimhudu, Y,; Kumar, K. A.; Neelima, S. and Sarma, A.S.R. 2017. Management of sunflower powdery mildew using fungicide. Int. J. Curr. Microbiol. App. Sci., 6(7): 1261-1264. 
Naik, K.S. and Nagaraja, A. 2000. Chemical control of powdery mildew of okra. Ind. J. Pl. Protect., 28(1):41-42.

Pukdee, S., and Sardsud, U. 2007. Use of acetic acid, peracetic acid and acetate salts for controlling green mold on tangerine cv. Sai Num Phueng. J. Agricultural Science. 38(5): 193-196.

Reuveni, M.; Gur, L. Farberm A. 2017. Development of improved disease management for powdery mildew on mango trees in Israel. Crop Protection, 30: $1-8$.

Shah, Y.A.; Bugti, G.A.; Feng, L. H.; Bin, W.; Shah, F. .; Mar, J.M. and Long, Y. 2016. Epidemiology and management of powdery mildew of sunflower. J. Entomology and Zoology Studies. 4(4):97-105.

Suresha, P.G.; Kulkarni, V. V.; Supraya, S.M. and Govindappa, M.R. 2017. Evaluation of experimental hybrids for powdery mildew tolerance in sunflower (Helianthus annuus L.). Int. J. Curr. Microbiol. App. Sc., 6(7):1716-1728.

Thipaksorn, C.; Rattanapanone, N. and Boonyakiat, D. 2012. Effects of peroxyacetic acid, peroxycitric acid, sodium bicarbonate, potassium sorbate, and potassium metabisulfite on the control of green moldin Sai Nam Phueng tangerine fruit. CMU. J. Nat. Sci., 11(2):203-21.

Yanar, Y.; Yanar, D. and Gebologlu, N. 2011. Control of powdery mildew (Leveillula taurica) on tomato by foliar sprays of liquid potassium silicate (K2SiO3). African J. Biotechnol., 10: 3121-3123.

Younes, N.A. and Abo-Eltoser, K.A. 2012. Screening of some okra (Abelmoschus esculentum L.) genotypes to powdery mildew resistance and yield under agro0climatic conditions of Assuit, Egypt. Int. J. Agric. and Economic Devel., 2(1):59-76.

Zhang, S.; Mersha, Z.; Vallad, G.E. and Huang, C. 2016. Management of powdery mildew in squash by plant and alga extract. Plant Pathol. J., 32(6): 528-536.

(Received 25/10/2017;

in revised form 20/11/2017) 


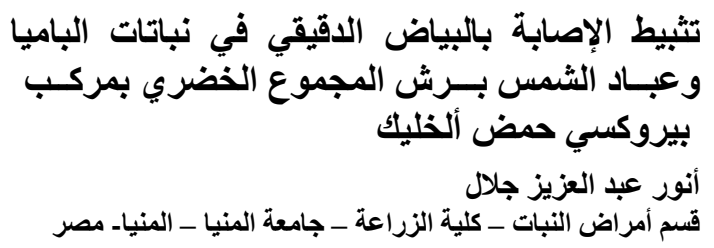

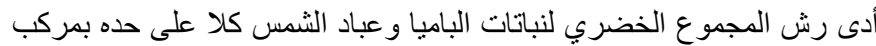

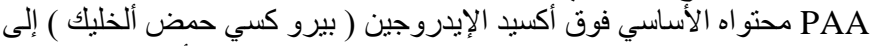

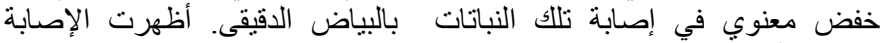

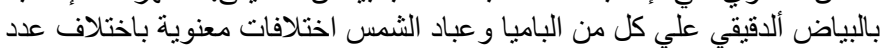

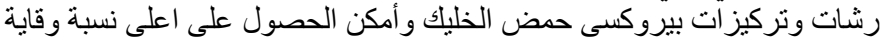

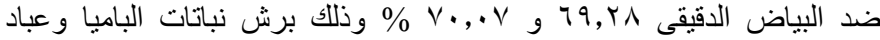

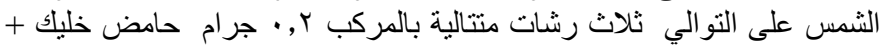

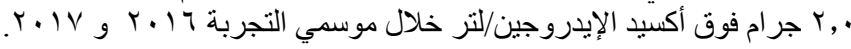

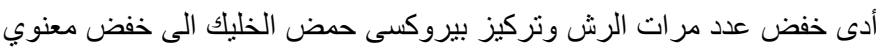

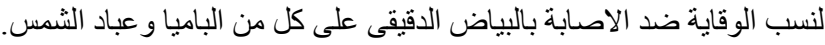

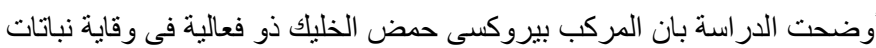

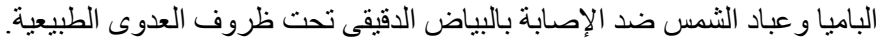

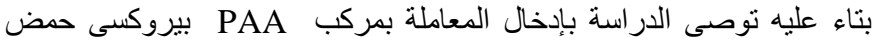

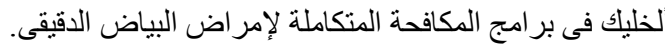

